\title{
PENGAMALAN AJARAN AGAMA PADA MASYARAKAT \\ EKONOMI LEMAH DI KECAMATAN PORTIBI KABUPATEN PADANG LAWAS UTARA
}

\author{
Ismail $^{1}$, Arno Ajahari Siregar ${ }^{2}$ \\ Program Studi Sosiologi Agama \\ Fakultas Ilmu Sosial UIN Sumatera Utara
}

ismailmarzuki@uinsu.ac.id

\begin{abstract}
ABSTRAK
Tujuan penelitian ini adalah untuk mengetahui pengamalan ajaran agama yang dilakukan oleh masyarakat ekonomi lemah di Kecamatan Portibi Kabupaten Padang Lawas Utara, untuk mendapatkan suatu kejelasan apakah benar taraf penghidupan itu punya pengaruh terhadap pengamalan ajaran agama di Kecamatan Portibi Kabupaten Padang Lawas Utara, untuk mengetahui kondisi ekonomi masyarakat di Kecamatan Portibi Kabupaten Padang Lawas Utara. Penelitian ini berlokasi di Kecamatan Portibi Kabupaten Padang Lawas Utara. Penelitian ini menggunakan penelitian kualitatif dengan teknik pengumpulan data yaitu obserasi, wawancara, angket, studi dokumen. Hasil penelitian ini menunjukkan adanya pengaruh yang negatif antara masyarakat ekonomi lemah terhadap pengamalan ajaran agama Islam di Kecamatan Portibi. Hal ini terjadi diakibatkan beberapa tuntunan pemenuhan kebutuhan pokok yang mendesak dalam kehidupannya sehari-hari. Walupun dalam taraf pemenuhan secara minimum telah mengkuras waktu, tenaga dan konsentrasi mereka sehinngga tidak memungkinkan terbukanya terbukanya kesadaran akan pentingnya melaksanakan ibadah kepada Allah SWT, dan menambah pengetahuan mereka terhadap nilainilai ajaran agama Islam, untuk meningkatkan pengamalan ibadah mereka.
\end{abstract}

Kata Kunci: Agama, Masyarakat Ekonomi Lemah 


\section{PENDAHULUAN}

Pada kehidupan manusia didunia ini Allah memberikan pedoman / mata aturan Yang harus dijadikan petunjuk dalam hidup yaitu Ad-Din (agama). Agama bagi manusia mengandung makna ganda yaitu pedoman untuk menempuh hidup didunia agar senantiasa memperoleh ketenangan dan kebahagiaan, serta sebagai penuntun beramal shaleh agar manusia mendapatkan kenikmatan dan kesenangan hidup diakhirat kelak. Untuk itulah maka didalam agama terkandung ajaran atas segenap aspek kehidupan manusia, berupa kewajiban yang mesti dilaksanakan maupun larangan yang harus ditiggalkan.

Pada dasarnya mengamalkan agama bukanlah pekerjaan yang sulit dilakukan oleh manusi, sebab pada fitrahnya manusia adalah ditunjuki pada agama dan disamping itu juga manusia sudah cukup dengan potensi-potensi yang ada pada dirinya sendiri sehingga dapat mengamalkan ajaran agamanya. Selain itu perintah-perintah agama hanya menjadi kewajiban dalam batas kemamapuan yang bersangkutan. Bahkan segal tingkah laku serta ucapan manusia dapat berupa nilai ibadah oleh agam apabila dilakukan dengan niat ikhlas karena Allah SWT.

Muthahhari (1984:44) mengatakan agama juga merupakan kebutuhan-kebutuhan fitrah dan emosional manusia dan merupakan satu-satunya sarana untuk memenuhi kebutuhan-kebutuhan fitrah manusia yang tak satupun dapat menggantikannya. Namun realitanya mengamalkan agama sering dirasakan sebagai beben berat, sehingga tidak jarang ditinggalkan, jika dipandang dari segi lahiriyah maka permasalahan ekonomi adalah meruppan salah satu penyebab orang mengabaikan pengamalan agama. Orang lebih cenderung untuk berkiprah mengejar dunia tanpa memperhitungkan asfek uhkrawi. Mereka berpacu mengejar kekayaan meskipun kadang ditempuh dengan jalan yang bathil, sementara agama hanya dijadikan sebagai simbol yang hanya diamalkan pada saat-saat perlu.

Disisi lain kesulitan ekonomi dapat cendrung memebuat orang mengamalkan ajaran agama. Nabi sendiri mengakui bahwa orang fakir itu hampir bisa kafir. Sebagaimana yang berbunyi dalam hadist Nabi Muhammad SAW:

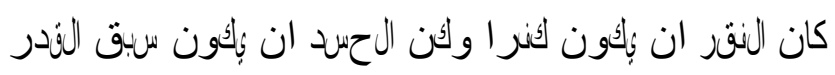

Artinya: Hampir saja kefakiran itu membawa kepada kekupuran dan hampir saja kedengkian itu membawa kepada mendahului takdir ( $\mathrm{HR}$, Abu Na'im fi Haliyah). 
Tetapi sebaliknya dengan pengamalan agama mestinya orang dapat dengan hidup lebih layak atau setidaknya terlepas dari kekafiran, sebab Islam sendiri baik lewat wahyu -Nya maupun hadist Rasulullah SAW telah menetapkan kerangka acuan agar manusia terlepas dari kemelaratan.

Secara realita yang terlihat bahwa pengamalan ajaran agama bahwa sering ditinggalkan disebabkan karna kesibukan untuk berkerja, oleh karena itu antara pengamalan agama dengan ekonomi jelas saling mempengaruhi dan berhubungan kepada kenyataan rohani( keimanan) dan perilakunya sehari-hari di dalam kehidupan. Hal inilah yang menyebabkan dan menarik perhatian bagi penulis untuk meneliti sejauhmana pengamalan ajaran agamana yang dilakukan oleh masyarakat ekonomi lemah dan bagaiman bandingannya dengan masyarakan ekonomi menengah ke atas. Berdasarkan latar belakang di atas, maka peneliti tertarik untuk melakukan penelitian dengan mengangkat judul Pengamalan Ajaran Agama Pada Masyarakat Ekonomi Lemah Di Kecamatan Portibi Kabupaten Padang Lawas Utara. Adapun yang menjadi fokus penelitian ini adalah:

a. Untuk mengetahui pengamalan ajaran agama yang dilakukan oleh masyarakat ekonomi lemah di Kecamatan Portibi Kabupaten Padang Lawas Utara

b. Untuk mendapatkan suatu kejelasan apakah benar taraf penghidupan itu punya pengaruh terhadap pengamalan ajaran agama di Kecamatan Portibi Kabupaten Padang Lawas Utara

c. Untuk mengetahui kondisi ekonomi masyarakat di Kecamatan Portibi Kabupaten Padang Lawas Utara.

\section{KAJIAN PUSTAKA}

\section{A. Defenisi Agama}

Beberapa pengertian agama yang akan dijelaskan dalam bab ini adalah pengertian secara umum, karena pengertian tentang agama sangat banyak sekali, sesuai dengan hakekat agama yang ada, titik pandangan para ahli itu sendiri dan tergantung juga kepada masalah penekanan titik masalahnya.

Menurut Nasir (1982:68) kalimat agama berasal dari bahasa sansekerta, sama artinya dengan "peraturan" dalam bahasa kita. Ada juga yang mengatakan kalimat agama dalam bahasa sansekerta itu asalnya terdiri dari dua suku kata, yaitu suku kata "a" dan "gama". Yang pertama berarti "tidak" dan yang kedua berarti "kacau” jadi manakala disatukan suku kata a dan gama, maka mempunyai arti tidak kacau. 
Nasution (2006:24) Ada yang mengartikan "a" tidak sedangkan "gama" pergi berarti tidak pergi, tetap ditempat, diwarisi turun temurun. Scharf (2004:34) Arti ini dapat dipahamkan dengan melihat hasil- hasil yang diberikan oleh peraturan-peraturan suatu agama pada moral atau material pemeluknya, seperti yang diakui oleh umum orang yang mempunyai pengetahuan. Agama sebagaimana tersebut diatas mempunyai arti lebih luas dari sekedar peraturan, karena agama melengkapi peraturan-peraturan yang bersipat dunia dan yang bukan duniawi (ukhrowi). Agama juga kepercayaan terhadap adanya wujudwujud spiritual(gahaib).

Maka untuk mengambil suatu pengertian yang kuat tentang defenisi agama maka perlu adanya pendekatan lain agar supaya defenisi agama itu sesuai dengan agama Islam sebagaimana yang dimaksud dalam skripsi ini dengan mengetahui unsur - unsurnya yang pokok tanpa juga menolak secara radikal adanya unsur - unsur yang ada pada agama lain. Unsur -unsur penting bagi agama ( khusunya agama Islam ) antara lain:

1. Tauhid yang tulen dimana seluruh ummat Islam di wajibkan mempunyai hubungan yang langsung dengan Allah yang maha kuasa dalam arti yang sepenuhpenuhnya, dan tidak seorang mana juga yang mempunyai hak lebih dari lainya dalam hal ini, dengan tidak melupakan bahwa perhubungan langsung itu adalah dengan pelajaran dan menrut kesunguhan seorang itu dalam usaha nya mencari jalam dalam hal ini.

2. Persamaan dan persaudaraan di antara seluruh pemeluk agama ini. Kedua sifat ni harus menjadi dasar fikiran dan pengetahuan untuk memahamkan segala peraturan yang di berikan agama ini dan perkerkembangan masyarakat harus didasarkan atas dasar tersebut.

3. Dasar permusyawaratan dalam segala hal mengenai kepentingan umum yang belum ada ketentuan definisinya dari pada Allah dengan berdasrkan salah satu unsyur yang ada dalam alqur'an atau hadist nabi atau perbuatan dan perkataan sahabat-sahabat nabi.

4. Keadilan dalam segala peraturan dan laranganya yang dibawanya, serta dapat memilhara dasar keadilan tersebut pada setiap peraturan dan perundang undanganya yang diberikan.

Ali (1996:9), agama ialah kepercayaan akan adanya Tuhan Yang maha Esa dan mempedomani hukum yang telah diwahyukan kepada utusan-Nya untuk kebahagiaan hidu manusia di dunia dan diakhirat. Menurutnya ciri-ciri agama ialah: 
1. Mempercayai adanya Tuhan Yang Maha Esa.

2. Mempunyai kitab suci dari Tuhan Yang Maha Esa.

3. Mempercayai rasul atau utusannya dari Tuhan Yang Maha Esa.

4. Mempunyai hukum sendiri bagi kehidupan penganutnya berupa perintah dan petunjuk.

Harun (1985:9) mengatakan agama juga disebut dalam bahasa arab yaitu Ad-Din dalm bahasa semit disebut dengan undang-undang atau hukum, dalm bahasa arab kata ini mengandung arti menguasahi, mendudukkan dan patuh, utang, balasan dan kebiasaan.

Mahmud juga menjelaskan Bila lafal din disebut dalm rangkaian dinullah, maka dipandang datngnya agama itu dari Allah, bila disebut dinun nabi maka nabilah yang melahirkan dan menyiarkan, dan bila disebut dinul ummah, karena dipandang bahwa manusia yang diwajibkan memeluk dan menjalankan. Ad-din bisa juga berarti syari'ah : yaitu nama dari peraturan- peraturan dan hukum-hukum yang disyari'atkanoleh Allah selengkapnya atau prinsip- prinsipnya saja, diwajibkan kepada kaum muslimian untuk melaksanakannya, dalm mengikat hubungan mereka dengan Allah dan dengan manusia.

\section{B. Agama Sebagai Sumber Kemanusiaan}

Menurut Nasir kalau melihat latar belakang agama yang diturunkan Tuhan kepada manusia, maka disitulah kita dapat mengetahui secara jelas tujuan agama bahwa ternyata agama itu bertujuan untuk memberikan kebahagiaa kepada manusia, damai dan selamat dunia dan akhirat, bahwa tujuan yang dimaksud adalah didalam rangka memanusiakan manusia. Karena manusia berdasarkan yang dimilikinya saja tidak dapat menjamin objektivitas, dimana antara satu dengan yang lainnya mengenal berpikir, berperasaan dan bertingkah laku.

Menurut Pdajar (1978:7) mengatakan manusia berkemauaan bebas, artinya berbeda dengan makhluk lainnya karena ia dilengkapi dengan akal pikiran yang melahirakn kemampuan untuk berpikir dan menentukan sikap. Kemauan bebas itu terdapat pada manusia dalm mengahadapi kehidupan di dunia pana ini. Oleh karena itulah diperlukan agama sebagai tolak ukur atau panduan berbuat agar ia tidak mempergunakan akalnya dengan sebebas-bebasnya.

Manusia tanpa agama cenderung untuk merealisir unsur-unsur dasar kemanusiaannya tanpa mengenal batas misalnya: berpikir bebas tanpa mengenal ikatan- 
ikatan, berperasaan tanpa adanya tenggang rasa, bertingkah laku tanpa mengenal baik, burk atau halal dan haram, dan bersiakp tanpa mnagadakan pertimbangan-pertimbangan. Kalau demikian kelakuan manusai, maka kemudian manusia akan meruntuhkan nilai-nilai kemanusiaannya sendiri dan berubahlah dari makhluk Tuhan yang tinggi derajatnya menjadi makhluk Tuhan yang hina.

\section{Kebutuhan Manusia Terhadap Agama}

Sebelum menjelaskan tentang kebutuhan manusia terhadap agama, maka akan dibahas terlebih dahulu beberapa segi dari manusia itu sendiri antar lain Kondisi manusia, Status manusia, Tangung jawab manusia.

\section{Kondisi manusia}

Menurut Nasir bahan manusia hidup terdiri dari dua unsur rohani. Untuk menambuhkan dan mengembangkan hidup manusia secara seimbang, maka dua unsur tersebut di atas harus mendapat perhatian, terutama dalam masalah pemenuhan kebutuhan masing - masing, diamana unsur jasmani membuthkan pemenuhan yang bersifat phisik jasmaniah, seperti misalnya : makan, minum, berolahraga dan sebagainya, sedangkan unsur rohaninya, seperti mislanya : pendidikan agama, budi pekerti, kepuasan, kasih sayang dan sebagainya.

Apa bila kedua kebutuhan tersebut dapat dipenuhi dengan sebaik - bainya dan cukup, maka hidup manusia akan harmonis, namun sebaliknya apabila salah satunya tidak terpenuhi, maka akibatnya hidup manusia akan mengalami kepincangan. Kedua kebutuhan tersebut sangat erat hubungannya dengan usaha menciptakan hidup bahagia, kerena banyak sekali kenyataan-kenyataanya yang dapat kita lihat, seperti misalnya seorang yang secara materil diadang mampu, seolah-olah tak ekurangan sesuatu apapun, namun karena tidak diimbangi oleh kesiapan mental, maka material itu sendiri akhirnya harus menjadi beban belaka, begitu pula orang yang sudah mempunyai setatus sosial yang cukup tinggi, tanpa disertai kesiapan mental, juga akhirnya dapat menghilang kan sifat mkemanusianya, munsulah sifat sombong, congkak, kuran tengan rasa dan sebagainya.

Namun juga ketidakbahagiaan itu bukan cuma di sebabkan dari segi mental, tetapi dari sebab material, seperti misalnya orang yang pendidikanya sudah tinggi, agamanya kuat, tetapi dalam segi material kurang, phisik kurang sehat, maka juga akan mendatangkan kemungkinan hidup tidak bahagia. Oleh sebab itu kondisi manusia pada hakekatnya menutut agar semua kebutuhan - kebutuhan itu dapat di penuhi dalam rangka 
mewujudakan hidup yang harmonis dan bahagia, termasuk juga kebutuahan rohani seorang terhadap agama.

2. Status manusia

Sebagaimana pada uraian di muka, bahwa manusia merupakan mahluk Allah yang berstatus khlifah di atas bumi. Dengan status itulah manusia diciptakan oleh Allah SWT, dengan bentuk yang paling banyak dalam segi jasmani maupun rohaninya. Dalam segi jasmaninya di perlengkapkan dengan perlengkapan - perlengkapan yang cukup dan sempuran, sehingga kalau di bandingkan dengan mahluk - mahluk Allah yang lainya, maka mansia yang paling baik dan sempurna. Dalam segi rohaninya juga demikian, manusia memiliki rohani yang lebih unik dan kompleks di bandingkan dengan mahluk mahluk lainya, manusialah satu - satunya mahluk lainya, manusialah akal dan dialah yang mempunyai kata hati.

Dengan demikian mamnusia dengan kelengkapan-kelengkapan yangdimiliki dan kelebihan - kelebihan yang ada pada permukaan yang paling atas sekali di dalam garis horiszontal sesama mahluk. Manusia dalam kedudukanya bukan berhamaba kepada mahkluk-makhluk dimana mahluk-mahluk itu ada di bawah permukaan garis horizon tersebut, tetapi manusia menjadi khalifah bagi semua yang ada di garis horizon, dan manusia cuma mengenal satu garis vertikal didalam berhamba, yaitu kepada Allah, sebagai pencipta ( kholiq ).

Dengan akal dan kesadarnya manusia mengakui Allah adalah asal dari segalanya, Allah selalu bersamanya dimana berada, manusia menyadari bahwa dirinya tidak bisa terlepas dan melepaskan diri dari ketentuan dan aturan Allah, baik yang berlaku untuk semua .mahluknya (sunnah alam) ataupun ketentuan yang khusus untuk manusia (addien/ Agama). Status manusia sebagai khlaifah di atas permukaan bumi dan sekaligus di tengah-tengah kehidupan mahluk-mahluk Allah, maka kebutuhan akan agama sudahlah pasti, agar supaya dapat membawakan tugasnya dengan sebaik - baiknya dalam rangka mewujudkan ketentram hidup, kedamaian, keselamatan dan kesajahteraan.

Scharf mengatakan karena agamalah yang mengajarkan manusia mengenal Tuhanya dan menjelaskan cara-cara berhubungan dengan sang pencipta tersebut, di ajarkan pula cara- cara berkomunikasih dengan sesamanya, dengan kehidupanya dan dengan lingkungan. Karena agama dan kepercayaan dapat mempersatukan semua orang kedalam suatu komunitas. ${ }^{20}$ 
3. Tangung jawab manusia.

Manusia mempunyai banyak kelebihan dari makhluk-makhluk Tuhan lainya, dan kelebihan itulah justru yang menjadi ciri khas dari manusia. Hanya manusialah yang mempunyai akal ( ratio ) dan hanya manusia pulalalah yang mempunyai kata hati. Sehingga ada ungkapan yang mengatakan bahwa " manusia adalah hewan yang berfikir / berbicara" ada juga yang mengatakan bahwa " manusia adalah mahluk yang suka bertanya".

Ungkapan-ungkapan itu prinsipnya sama saja, dimana keduanya mengungkapkan tentang kelebihan yang dimiliki manusia dan sebenarnya itu pulalah yang termasuk salah satu sebab manusia dikatakan oleh Allah SWT. Dengan mahluk yang baik kejadianya (ashani taqwin). Di dalam pertumbuhan dan perkembangan manusia kalu kita, maka banyak sekali pengaruh-pengaruh yang menyebabkan manusia berbuat sesuatu atau meningalkan, baik pengaruh itu dari dalam (interm) yang berupa instink maupun pembawaan, atau pengaruh dari luar ( ekstern ) yang berupa lingkungan alam sekitar.

Pada masa-masa permulaan dari perkembangan seseorang memang instink dan pembawaan besar sekali pengaruhnya termasuk juga pengaruh lingkungan alam sekitar, sebagainmana hal ini telah di sinyalir oleh schopenhouver dalam teori konvergesinya. Tetapi dalam perkembangan berikutnya, setelah mencapai dewasa, maka disamping dua pengaruh tersebut, ada lagi satu ketentuan dalam diri manusia yang mempengaruhi terhadap apa yang harus di lakukan.

Kekuatan inilah yang disebut dengan" Aktifitas priody, “ di mana aktifitas peribadi ini kadang-kadang tidak/kurang sesuai dengan pembawaanya sendiri, bahkan juga tidak sesuai dengan keadaan lingkungan alam sekitrarnya. Dengan adanya aktivitas pribadi inilah manusia dewasa mempunayai tengung jawab yang sifatnya sangat subyektif, tergantung pada setiap individu yang ada.

Subyektivitas manusia akan melahirkan termacam - macam pendapat, pemikiran, interprestasi dan kesimpulan yang beraneka ragam coraknya sesuai dengan kebutuhan dan kepentinganya masing-masing. Oleh sebab itulah secara keseleruahan, manusia membutuhkan adanya pegangan, aturan yang bersifat umum sebagai standart umum di dalam menentukan mana yang baik dan tidak baik, mana yang pantas dan tidak baik, mana yang pantas dan tidak pantas dan sebagainya. Apalagi bahwa setiap apa yang yang di kerjakan manusia di dunia ini, pada hari kiamat akan dimintai pertangung jawabnya pleh Allah SWT, karena pada hakekatnya manusia sebagai mahluk Allah tidak dapat terlepas dan melepaskan diri dari hukum/peraturan Allah SWT, baik yang berlaku umum untuk seluruh ciptanya (sunnah alam) maupun yang berlaku khusus (ad dien/agama). 


\section{METODE PENELITIAN}

\section{A. Lokasi Penelitian}

Lokasi penelitian ini berada di kecamatan Portibi di Kabupaten Padang Lawas Utara dengan luas wilayah mencapai sekitar 73.600 hektar yang beribu kota kecamatan Gunung Padang Bolak. Kecamatan Portibi ini berbatasan dengan:

- Sebelah timur berbatasan dengan Kecamatan Barumun Tengah Kabupaten Padang Lawas.

- Sebelah barat berbatasan dengan Kecamtan Padang Bolak

- Sebelah utara berbatasan dengan Kecamatan Halongonan

- Sebelah selatan berbatasan dengan Kecamatan Sosopan.

\section{B. Jenis Penelitian}

Penelitian ini adalah penelitian lapangan (field research) dengan pendekatan penelitian kualitatif yaitu mengadakan penelitian dalam menghimpun data langsung terjun kelapangan. disamping itu di lengkapi dengan library research, yaitu dengan mengadakan study literatur yang relevan dengan masalah yang di teliti. Sumber data penelitian ini diperoleh dari inorman. Informan dalam penelitian berjumlah sebanyak 20 informan yang mewakili setiap desa masing-masing, dan ditambah satu orang tokoh agama dan adat yang keseluruhannya beragama Islam. penetapan sampel sebanyak tersebut diatas dianggap sudah representatif dari populasi penelitian ini. Jenis data yang dihimpun dalam penelitian ini dapat dibedakan menjadi dua jenis, yaitu data kualitatif : berupa pendapat, pandangan, pernyataan bsik lsngsung dari responden maupun dari literatur yang relevan dengan masalah yang ditelit. Kedua adalah data kuantitatif, yaitu data yang berbentuk angka-angka maupun data statistik dari kantor camat.

Sumber data dapat dibedakan menjadi dua, yaitu sumber data primer, yaitru : para responden yang telah ditetapkan menjadi sampel yang terdiri dari anggota masyarakat. Dan sumber data skunder, yaitu : diharapkan dari perintah desa setempat, KUA Kecamatan Portibi, Kepala Desa, Toko Masyarakat( agama dan adat) dan bukubuku yang berkaitan dengan masalah yang diteliti.

\section{Teknik Pengumpulan Data}

Teknik pengumpulan data dalam penelitian ini adalah observasi, wawancara, studi dokumen, dan angket:

a. Observasi, yaitu pengamatan langsung terhadap gejela-gejala yang berkenaan dengan masalah pengamalan ajaran agama dan hubungannya dengan ekonomi lemah di kecamatan Portibi. 
b. Wawancara, yaitu mengadakan serangkaian tanya jawab secara lisan kepad sumber data sebagai sumber data pelengkap bagi data primer.

c. Studi Dokumen berupa catatan-catatan, surat-menyurat, data hand copy serta soft copy resmi yang peneliti temukan di lapangan

d. Angket, yaitu mengajukan sejumlah pertanyaan tertulis kepada responden sesuai dengan masalah yang diteliti.

\section{Analisis Data Penelitian}

Data yang telah dihimpun akan dianalisis dengan mempergunakan pendekatan data kuantitatif dan kualitatif. Analisa kualitatif akan dilakukan terhadap data yang bersifat kualitatif, baik instrumen wawancara maupun lainnya. Sedangkat analisa kuantitatif diambil dan disajikan dengan menggunakan tabel dan perhitungan lainnya. Kualitatif akan diolah dan disajikan secara diskripsi dan analitik, serta diselingi dengan kutipan-kutipan yang dianggap perlu untuk masalah yang dibahas dalam penelitian Adapun pola berpikir yang dipergunakan untuk menarik kesimpulan akhirnya ialah dengan mempergunakan / mempedomi cara berpikir indukti, yaitu berpijak dari pemikiran/kesimpulan yang khusus ditarik menjadi kesimpuln yang umum.

\section{HASIL PENELITIAN DAN PEMBAHASAN}

\section{A. Pengalaman Ajaran Agama Pada Masyarakat Lemah}

Salah satu masalah yang dipunyai manusia yang sama tuanya dengan manusia itu sendiri dan implikasi permasalahannya dapat melibatkan keseluruh aspek kehidupan manusia tetapi tidak sering disadari kehadirannya ialah permasalahan ekonomi lemah. Dalam kehipan sehari-hari dimasyarakat ekonomi lemah adalah sesuatu yang nyata adanya, masyarakat ekonomi lebih itu lebih terasa apabila mereka telah membandingkannya dengan yang lain, ekonomi lemah sering dilukiskan sebagai kurangnya pendapatan untuk memenuhi kebutuhan hidup yang pokok, seperti pangan, pakaian, rumah sebagi tempat berteduh.

Klasifikasi atau penggolongan seseorang tergabung dalam kelompok masyarakat ekonomi lemah ditetapkan dengan menggunakan tolak ukur, tolak ukur yang umum dipakai adalah tingkat pendapatan dan kebutuhan relative. Tingkat pendapatan digunakan ukuran waktu kerja sebulan, maka siapa yang tergolong masyarakat ekonomi lemah dapat diketahui dari hasil pendapatannya sebulan, yaitu Rp. 500.000 per bulan. Tolak ukur yamg lain ialah yang dinamakan tolak ukur kebutuhan relatif per keluarga yang batasan batasannya dibuat berdasarkan atas batas minimal yang harus dipenuhi guna sebuah keluarga dapat melangsungkan kehidupannya secara sederhana dan memadai sebagai masyarakat yang layak, adapun tolak ukur relative tersebut sebagi berikut, tidak punya 
listrik, tidak punya sumur, rumah dinding papan, tidak punya biaya sekolah, tidak punya biaya untuk berobat minimal Rp. 500.000,- disaat diperlukan dan kebutuhan pangan juga tidak memadai.

Permasalahan ekonomi lemah tersebutlah yang saat ini sedang dialami sebagian masyarakat yang ada Di Kecamatan Portibi, oleh sebab itu saat ini mereka bekerja keras, tidak mengenal lelah bahkan tidak mengenal waktu guna untuk melangsungkan hidup mereka sehingga tidak heran jika sebagian masyarakat kecamatan portibi lalai dalam melaksanakan ajaran Agama karna setiap saat mereka selalu sibuk bekerja.

\section{Dalam Bidang Ibadah}

Tiap-tiap peribadi pasti memiliki kepercayaan, meskipun bentuk dan pengungkapannya berbeda-beda. Dan pada dasarnya manusia memang membutuhkan kepaercayaan, kepercayaan itu akan membentuk sikap dan prilaku dan pandangan hidup seseorang. Dalam sejarah ummat manusia, akan selalu dicumpai bentuk kepercayaan. Proses pencarian dan kepercayaan oleh manusia tidak akan berhenti selalu ada selama manusia masiah ada.

Tentang kepercayaan ini pada umumnya orang memberikan gambaran sebagai suatu tempat pengembalian segala masalah yang diluar jangkauan batas kemampuan akal dan pikiran manusia. Dengan kata lain apa yang menjadi pusat kepercayaan itu dipandang memeliki sesuatu yang lebih tinggi.

Dalam proses manusia mencari kepercayaan akan dijumpai adanya bermacammacam konsep dari yang masih sederhana sampai kepada yang sempurna. Dan setiap agama pasti memiliki konep dasar kepercayaan yang oleh para ahli theologi disebut sebagai pengertian-pengertian dasar keagamaan. Konsep agama itu dikenal dalam agama Islam dengan Istlah "Aqidah Islam". atau pokok-pokok keperyaan kepercayaan Islam.

Masalah akidah merupakan hal yang sangat penting bagi ummat Islam dimana saja berada serta apapun yang menjadi pekerjaannya, akaidah merupakan hal paling pokok untuk menuntun ummat Islam kepada kehidupan yang diridhoi oleh Allah SWT, sebab akidah itu adalah kepercayaan dan keyakinan. Menurut Syaltout (1990:18) menyatakan bahwa adapun kepercayaan adalah segi teoritis yang dituntut pertama-tama dan terdahulu. Dari segala sesuatu keimanan yang tidak boleh di campuri wasangka dan tidak dipengaruhi oleh keragu-raguan. 
Pendapat diatas dapat diketahui bahwa soal akidah adalah masalah kepercayaan dan keyakinan yang ada secara sungguh-sungguh. Didalam hati nurani ummat Islam yang sangat mendasar dan tidak boleh ada keraguaan. Lebih lanjut Muhammat Syaltout mengatkan

Syaltout (1990: 20) kepercayaan itu didalam posisi ummat Islam adalah pokok yang dibina di atasnya peraturan-peraturan agama (syari'at). Sedangkan perundangundangan agama itusendiri adalah hasil yang dilahirkan oleh kepercayaan tersebut. Maka dengan demikian tidaklah terdapat syari'at dalam Islam melainkan adanya kepercayaan, sedangkangkan syari'at tidak akan berkembang melainkan dibawah keperyaan.

Keterangan tersebut dapat dipahami antar aqidah dan syari'at harus saling berbaringan, dengan kata alin suatu keyakinan yang kuat kepada Allah harus dibarengi dengan ibadah kepada Allah serta mengamalkan ajaran-Nya dalam kehidupan seharisehari. Pokok-pokok Ibadah yang wajib dilaksanakan dalam ajaran Islam adalah: sholat, puasa, zakat, haji bagi yang mampu dan mengucapkan dua kalimah syahadat dalam shalat sebagai penyempurna ajaran Islam, maka genaplah jumlahnya menjadi lima pokok-pokok Ibadah. Kelima pokok-pokok ibadah itu menyandang nilai-nilai yang agung membawa efek yang baik kepada orang yang melakasanakannya dan juga terhadap orang lain.

\section{Bidang Muamalah.}

Manusia sebagai makhluh sosial selalu berhajat antara satu dengan yang lainnya dalm mempertahankan exksistensi kehidupannya, isalamadalah agama yang paripurna telah mengatur hubungan tersebut. Islam merupakankode etik dan pedoman bekerja disetiap perilaku sehari-hari. Tenggang rasa atau kepedulian masyarakat terhadap lingkunagn masyarakat mengenai keamanan dan kebersiahan masyarakat.

Seseorng muslim yang teguh dan kuat imannya tidak sekedar menganggap agama sebagai keyakianan ideal yang abstrak dan sekedar menyembah secara setatis, teratur setiap hari. Tetapi Islam adalah etiaka kehidupan Islam adalah sebuah petunjuk yang sangat kuat kesemua aspek kehidupan tiap muslim, agar selalu menjaga titik berat kegiatannya sepenuhnya menurut Islam.

Malahan problem kemiskinan tidak perlu lagi untuk mencari dan merumukan teori pembahasannya, malah yang perlu ialah data kongkrit bahwa kemiskinan adalah bencana sosial yang kin mengancam exksistensi ummat Islam, didalam ajaran Islam nampak suatu upaya untuk menciptakan keadialn sosial yang merata kepada kepada 
setiap anggota masyarakat Islam. tidak dibenarkan adanya sebagian menjadi kaya dan menguasai sistem perekonomian.

Perampasan hak orang lain merupakan suatau perbuatan yang terketuk, mengambil harta orang ain secara paksa melalui jalan kekerasan merupakan perbuatan yang sangat dimurkai oleh Allah SWT.

Akan hal nya aspek muamalah ini. Penulis mengemukakan beberapa indikasi sebagai gambaran hubuangan sesama anggota masyarakat Portibi. Sebagai berikut :

1. Tingkat kepedulian antar sesama anggota masyarakat.

2. Tingkkat kepedulian akan ketenteran danketertiban.

3. Tingkat kepedulian akan lingkungan.

Untuk lebih jelasnya penulis mengkelasifikasikan jenis muamalah kedalam tabel dari hasil penyebaran angket pada masyarakat ekonomi lemah.

1. Kerukanan bertetangga

Tabel 1.1

Alternatif jawaban ekonomi lemah tentang kerukunan bertetangga

\begin{tabular}{|c|l|l|l|}
\hline No & Alternatif Jawaban & Jumlah & \multicolumn{1}{|c|}{ Persentase } \\
\hline $\mathbf{1}$ & Penting & 48 & $48 \%$ \\
\hline $\mathbf{2}$ & Sangat penting & 39 & $39 \%$ \\
\hline $\mathbf{3}$ & Kurang Penting & 13 & $13 \%$ \\
\hline \multicolumn{2}{|c|}{ Jumlah } & $\mathbf{1 0 0}$ & $\mathbf{1 0 0 \%}$ \\
\hline
\end{tabular}

Dari tabel di atas dapat kita lihat jumlah masyarakat ekonomi lemah yang menganggap penting kerukunan bertetang yaitu 48 orang, dan yang menganggap sangat penting 39 orang, dan 13 orang menganggap kurang penting. Dari hasil wawancara penulis dengan sebagian masyarakat ekonomi lemah menyatakan sangat penting disebabkan karena ada maunnya. Dan yang menyatakan kurang penting adalah mereka yang jarang bersosialisai dengan tetangga, disebabkan karena kesibikan bekerja seharisehari, sehingga dengan tetanggapun jarang bertegur sapa.

2. Tingkat kepedulian akan ketenteraman.

Tabel 1.2

Alternatib Jawaban Masyarakat Ekonomi Lemah Terhadap Ronda Malan

\begin{tabular}{|c|l|l|l|}
\hline No & Alternatif Jawaban & \multicolumn{1}{|c|}{ Jumlah } & \multicolumn{1}{|c|}{ Persentase } \\
\hline $\mathbf{1}$ & Selalu Ikut & 0 & $0 \%$ \\
\hline $\mathbf{2}$ & Kadang-Kadang & 11 & $11 \%$ \\
\hline $\mathbf{3}$ & Tidak Pernag & 89 & $89 \%$ \\
\hline \multicolumn{2}{|c|}{ Jumlah } & $\mathbf{1 0 0}$ & $\mathbf{1 0 0 \%}$ \\
\hline
\end{tabular}


Dari tabel di atas dapat kita pahami bahwa jumlah yang selalu ikut ronda malam 0 orang, mereka beralasan karena masyarakat Kecamatan Portibi tidak diwajibkan untuk ronda. Dan jumlah yang tidak pernah sebanayak 89 orang. Sesuai dengan hasil wawancara penulis dengan sebagian responden, mereka yang tidak pernah ikut ronda disebabkan karena di Kematan Portibi itu jarang terjadi keributan, kemalingan. Dang jumlah yang kadang-kadang ikut ronda sebanyak 11, ini mereka yang berada dipinggiran kota, seperti di Purbabangun, dan Aek Haruaya.

\section{Kepedulian Lingkungan}

Manusia sebagai makhluk sosial selalu berhajat antara satu dengan yang lainnya dalam mempertahankan exsistensi kehidupannya.

Seorang muslim yang teguh keimanannya tidak hanya menganagap agama sebagai keyakinan ideal yang abstrak yang hanya sekedar menyembah secara statis, teraturan setiap hari maupun esok. Namun ia juga memperhatiakan sesamanya dan lingkungannya. Untuk mengetahui bagaimana tingkat kepedulian masyarakat ekonomi lemah di Kecamatan Portibi terhadap lingkungan mari kita lihat tabel berikut.

Tabel 1.3

Pelaksanaan Gotong Royong Pada Masyarat Ekonomi Lemah Di Kecamatan Portibi

\begin{tabular}{|c|l|c|c|}
\hline No & \multicolumn{1}{|c|}{ Alternatif Jawaban } & Jumlah & Persentase \\
\hline $\mathbf{1}$ & Selalu Ikut & 29 & $29 \%$ \\
\hline $\mathbf{2}$ & Kadang-Kadang & 47 & $47 \%$ \\
\hline $\mathbf{3}$ & Tidak Pernag & 24 & $24 \%$ \\
\hline \multicolumn{2}{r|}{ Jumlah } & $\mathbf{1 0 0}$ & $\mathbf{1 0 0 \%}$ \\
\hline
\end{tabular}

Dari tabel di atas dapat di mengerti bahwa jumlah yang selalu ikut bergotong royong sebanyak 29 orang. Dan 47 orang yang kadang-kadang ikut, ini adalah jumlah yang paling terbesar. Dan yang tidak pernah ikut sebanyak 24 orang. Sesuai dengan haasil wawancara penulis denagn Camat Kecamatan Portibi yaitu bapak Mandongar SH menyatakan masyarakat Portibi termasuk masyarakat yang susah diajak untuk kerja sama, setiap ada gotong royong peserta yang datang tidak pernah sesuai dengan yang diharapkan, dan kalupun datang jarang tepat waktu, alasan mereka karena selalu sibuk bekerja.

\section{PENUTUP}

Dari beberapa data dan fakta yang penulis temukan dalam kehidupan masyarakat Kecamatan Portibi yang tergolong kepada ekonommi lemah, jelas tampak adanya pengaruh yang negatif terhadap pengamalan ajaran agama Islam di Kecamatan tersebut. Hal ini terjadi diakibatkan beberapa tuntunan pemenuhan kebutuhan pokok yang 
mendesak dalam kehidupannya sehari-hari. Walupun dalam taraf pemenuhan secara minimum telah mengkuras waktu, tenaga dan konsentrasi mereka sehinngga tidak memungkinkan terbukanya terbukanya kesadaran akan pentingnya melaksanakan ibadah kepada Allah SWT, dan menambah pengetahuan mereka terhadap nilai-nilai ajaran agama Islam, untuk meningkatkan pengamalan ibadah mereka,

Dengan demikia kesenjangan ekonomi ini adalah pada akhirnya mengurangi tingkat pengetahuan mereka terhadap agama Islam, dan kemudian pada taraf selanjutnya pula kemiskinan pengetahuan ini dapat menimbulkan dan mempertinggi tingkat kemiskinan mereka, dan pada taraf selanjutnya kemiskinan itulah yang menyebabkan meraka lalai di dalm melaksanakan dan mengamalkan ajaran agama, karean selalu sibuk bekerja untuk memenuhi kebuituhan mereka.

\section{DAFTAR PUSTAKA}

A Malik Pdajar. 1978. Kuliah Agama Islam. Surabaya: Al-Ikhlas

A Mukti. 1996. Etiaka AgamaDalam Pembentukan Keperibadiaan. Yogyakarta: Yayasan Nida

Abdul Mutholib. 1988. Aliran Kepercayaan dan Kebatinan Di Indonesia. Surabaya: CV. Amin

Abdul Razak. 2006. Ilmu Kalam. Bandung: Pustaka Setia

Betty R Scharf. 2004. Sosiologi Agama. Jakarta: Prenada Media

Departemen Agama RI. 2005. Al-Qur'an dan Terjemhannya. Jakarta: J-ART

Departemen Agama RI. 1989. Al-Qur'an dan Terjemahannya. Semarang: Karya Toha Putra

Harun Nasution. 1985. Islam Ditinjau dari berbagai Aspek. Jakarta: Universitas Indonesia

Hasnah Nsution. 2006. Filsafat Agama. Jakarta: Istiqomah Mulia Press

Murtadha Muthahhari. 1984. Persfektif Al-Qur'an Tentang Manusi dan Agama. Bandung: Mizan

Sahilin A Anwar. 1982. Pokok-Pokok Pendidikan Agam Islam. Surabaya: AlIkhlas 
Syeh Mahmud Syaltout, Aqidah dan Syari'ah, (Bumi Aksara, Jakarta, 1990), hal. 18

W.J.S. Poerwadarminta, Kamus B Indonesia (Jakarta,PN Balai Pustaka,, 1982), hal. 553

Yayasan Al-Mu'min, Penuhilah Seruan Allah dan Rasul (Jakarta,Al- Mu'min, 2006), hal. 20 